\title{
Losy kobiet w obozach na Górnym Śląsku po zakończeniu II wojny światowej ${ }^{1}$ (wybrane zagadnienia)
}

Fates of the Women in the Camps in Upper Silesia after the Termination of World War 2

\begin{abstract}
The subject of the essay are fates of women in the camps in Upper Silesia after the termination of World War 2. These camps secured primarily the isolation against the nationality verification and displacement or exploitation as a slave workforce. The author indicates that rape, terror and murder were the actions undertaken by the degenerated guards, often with sadistic inclinations, who felt their impunity. The determinants of these events and the dynamics of victimization are discussed. Gradually, the physical violence was replaced with exterminating labour. After release from the camps the women found it very difficult to adapt to new conditions of life. It was often difficult for them, if not impossible, to start a family and raise children. They were left with deep trauma that haunted the former inmates until the end of their lives.
\end{abstract}

Keywords: victimization, women, rape, labour camps, Upper Silesia

Streszczenie: Szkic podejmuje temat losów kobiet w obozach na Górnym Śląsku po zakończeniu drugiej wojny światowej. Obozy te służyły przede wszystkim izolacji przed weryfikacją narodowościową i wysiedleniem lub wykorzystaniem jako niewolniczej siły roboczej. Autor wskazuje, że gwałty, terror i morderstwa były działaniami prowadzonymi przez zdegenerowanych strażników, często sadystów, którzy czuli się bezkarni, i omawia uwarunkowania tych zdarzeń oraz dynamikę represji. Stopniowo przemoc fizyczną zastąpiono bowiem wyniszczającą pracą. Po wyjściu w obozów kobiety miały duże trudności z adaptacją do nowych warunków życia. Często utrudniało to lub wręcz uniemożliwiało założenie rodziny, wychowywanie dzieci, pozostawiało silną traumę, która prześladowała byłe więźniarki do końca życia. Słowa kluczowe: represje, kobiety, gwałty, obozy pracy, Górny Śląsk

${ }^{1}$ Niektóre fragmenty tekstu były publikowane w mojej książce, zob. Z. Woźniczka, Represje na Górnym Ślasku po 1945 roku, wyd. 2, Katowice 2013. 
W czasie wojny kobiety podobnie jak mężczyźni były zamykane i represjonowane w różnego rodzaju obozach. Niemcy utworzyli nawet specjalne obozy dla kobiet, najbardziej znany z nich to Ravensbrück. W 1945 roku Armia Czerwona, tocząc ciężkie walki, zajmowała tereny Polski i Niemiec, ale towarzyszył temu terror wobec ludności cywilnej². Dotyczyło to też Górnego Śląska, gdzie na dużą skalę zdarzały się morderstwa, rabunki, masowe gwałty i wywózki ludzi oraz maszyn do Związku Radzieckiego³. Szybko odtworzono sieć hitlerowskich obozów, zamykając tam tysiące mężczyzn, kobiet i dzieci. Nie stworzono specjalnych obozów dla kobiet i dzieci, jedynie wydzielono dla nich osobne baraki. Kobiety i mężczyźni byli podani takiemu samemu terrorowi, zmuszano ich do niewolniczej pracy.

Powstanie obozów pracy i panujący tam terror był konsekwencją wielu czynników, ale też wpisywał się w całą falę represji, jakie spotkały Polaków po zakończeniu wojny. Nie sposób opisać całości tego złożonego problemu, ale celem tego artykułu jest pokazanie niektórych najbardziej typowych zagadnień dotyczących losu kobiet w powojennych obozach na Górnym Śląsku.

\section{Obozy pracy}

W Polsce między rokiem 1945-1950 było 206 obozów, w tym obozy pracy przymusowej, w których przetrzymywano Niemców, Ukraińców, Łemków i Polaków. Powstały one z wykorzystaniem infrastruktury dawnych niemieckich obozów koncentracyjnych, obozów jenieckich czy obozów dla robotników przymusowych. Obozy te podlegały Ministerstwu Bezpieczeństwa Publicznego (MBP) oraz Centralnemu Zarządowi Przemysłu Węglowego (CZPW). Już jesienią 1945 roku Departament Więziennictwa i Obozów MBP prowadził 131 placówek, w tym przede wszystkim więzień (z tego 7 centralnych), oraz 12 obozów pracy i 2 samodzielne kolonie rolne ${ }^{4}$. W chwili zakończenia wojny w obozach i więzieniach na ziemiach polskich podległych Ministerstwu Bezpieczeństwa Publicznego (MBP) było uwięzionych 50611 tys. osób,

2 W końcu lutego 1945 roku wpadł w ręce niemieckie i został przesłany do Adolfa Hitlera rozkaz dzienny marszałka Gieorgija Żukowa: „Śmierć Niemcom!”. W brutalnych słowach przekonywał on żołnierzy sowieckich, że nadeszła godzina zemsty na „kanibalach Hitlera”. „Dokonamy pomsty za wszystkich spalonych w diabelskich paleniskach, uśmierconych w komorach gazowych, zastrzelonych i umęczonych. Zemścimy się na nich okrutnie! (...) Biada ojczyźnie morderców! (...) Tym razem unicestwimy na wieki niemieckie plemię", cyt. za: D. Irving, Wojna Hitlera, tłum. B. Zborski, Warszawa 1996, s. 659.

${ }^{3}$ Zob. Z. Woźniczka, Represje na Górnym Ślasku..., dz. cyt., s. 79-122; Por. Wywózka. Deportacja mieszkańców Górnego Ślaska do obozów pracy przymusowej w Związku Sowieckim w 1945 roku. Faktografia, konteksty, pamięć, red. S. Rosenbaum, D. Węgrzyn, Katowice 2014.

${ }^{4}$ Archiwum Akt Nowych (dalej: AAN Warszawa) MBP, sygn. 5/5, Statystyka ruchu więźniów i sprawy inspekcyjno-administracyjne. 
w tym 2121 Niemców i 35428 volksdeutschów 5 . W lutym 1946 roku w więzieniach przebywało 120081 więźniów, w tym w obozach i więzieniach podległych MBP 61 894, pozostała częśc była w aresztach śledczych podległych Powiatowym Urzędom Bezpieczeństwa Publicznego (PUBP) i Wojewódzkim Urzędom Bezpieczeństwa Publicznego (WUBP). Pewien spadek liczby więźniów nastąpił po amnestii w 1947 roku $(90000 \mathrm{w}$ więzieniach i około 60000 w aresztach śledczych PUBP i WUBP. W 1950 roku w więzieniach przebywato 98 923, a w 1951 roku mniej, gdyż 74733 więźniów ${ }^{6}$. W sumie w latach 1945-1947 w więzieniach i obozach zmarło 6140 osób ${ }^{7}$.

\section{Codzienność w obozach}

Strażnikami w obozach w większości byli ludzie o bardzo niskim wykształceniu, zdemoralizowani przez wojnę i bardzo często wywodzący się z tak zwanego marginesu społecznego. Nierzadko byli to kryminaliści i sadyści. Komendanci i władze obozów zazwyczaj również reprezentowali niski poziom etyczny. W tej sytuacji powszechne było znęcanie się nad więźniami, pijaństwo, złodziejstwo i zaniedbywanie obowiązków. Z biegiem czasu starano się zaprowadzić porządek, między innymi po to, aby zwiększyć efektywność wykorzystania siły roboczej osadzonych. Mówiono o tym podczas Krajowej Odprawy Naczelników Wojewódzkich Wydziałów Więziennictwa, w dniach 20-21 października 1947 roku w Warszawie ${ }^{8}$. O złym poziomie kadr więziennictwa debatowano także podczas IV Ogólnokrajowej Odprawy Naczelników Więzień i Obozów odbywającej się w świetlicy Departamentu Więziennictwa w dniach 16-18 maja 1949 roku? .

W relacjach dotyczących losu kobiet osadzonych w obozach zaobserwować można dużą różnorodność. W niektórych dużo się pisze o terrorze, zabójstwach, gwałtach, a w innych takie wzmianki są rzadkie lub wręcz nie występują. Można sądzić, że zdarzenia takie nie dotknęły bezpośrednio opisujących. Nie sposób też wykluczyć, że dana osoba nie chciała o tym pisać lub tego wspominać. Wydaje się, że najwięcej bezmyślnego bicia oraz mordowania i sadyzmu doświadczono ze strony strażników w 1945 roku. Wówczas dopiero organizowano struktury i było też wiele tak zwanych dzikich obozów,

5 W. Borodziej, Wstęp [w:] Niemcy w Polsce 1945-1950. Wybór dokumentów, t. 1, red. W. Borodziej, H. Lemberg, tłum. M. Cegielska, Warszawa 2000, s. 85.

${ }^{6}$ H. Dominiczak, Organy bezpieczeństwa PRL 1944-1990. Rozwój i dziatalność w świetle dokumentów MSW, Warszawa 1997, s. 70.

7 AAN Warszawa MBP, sygn. 5/5.

${ }^{8}$ AAN Warszawa MBP, sygn. 1/38, s. 76, Protokół z Krajowej Odprawy Naczelników Wojewódzkich Wydziałów Więziennictwa, w dniach 20-21 października 1947, Departament Więziennictwa, Warszawa.

9 AAN Warszawa MBP, sygn. 1/41. 
tworzonych naprędce. Strażnikami zostawali przypadkowi ludzie, którzy bez zahamowań stosowali przemoc, ponieważ czuli się bezkarni. Panował bałagan, nad którym z trudem udało się jako tako zapanować.

W obozie w Potulicach na Pomorzu strażnicy często nakazywali więźniom dręczenie członków najbliższej rodziny, w tym synom bicie własnych ojców czy matek, na przykład: „pewnego razu zmuszono mężczyznę, aby zbił własną matkę. Gdy ten wzbraniał się przed tym, powiedziała mu, zrób to chłopcze, bo mnie to nie będzie bolało" ${ }^{10}$. W Dzierżoniowie na Śląsku w miejscowym areszcie milicjanci znajdujące się tam Niemki, rozebrane do naga, polewali gorącą wodą lub zamykali w zimnej piwnicy. Kazano im także tańczyć przed milicjantami ${ }^{11}$. W więzieniu przy sądzie w Chełmie na Pomorzu strażnicy i funkcjonariusze UB dopuszczali się indywidualnych i zbiorowych gwałtów na osadzonych:

Wyprowadzali więźniarki z celi i gwałcili albo na korytarzu, albo w łaźni w piwnicy. Pani T. była gwałcona około pięciu razy. Ponadto kilka razy została pobita pejczem. Gwałcicielami byli m.in. funkcjonariusz UB Pietrzykowski i porucznik UB Szatkowski. Imion wymienionych funkcjonariuszy pani T. nie pamięta. Gwałcili ją również inni funkcjonariusze $\mathrm{UB}$, ale nie pamięta ich nazwisk ${ }^{12}$.

Jednym z najgorszych obozów na Górnym Śląsku był obóz NKWD w Toszku ${ }^{13}$. Tym bardziej dziwi stosunkowo dobre odnoszenie się do nielicznych przebywających tam kobiet. Zatrudniano je przede wszystkim w pralni i w kuchni. Często też sprzątały w domach rodzin oficerów i dostawały za to coś do jedzenia. Niekiedy wydawały żywność kolumnom więźniów kierowanym do pracy. Jedna z więźniarek wspominała:

Żadna z kobiet nie zmarła w obozie w Toszku. Strażnicy obozowi traktowali nas zupełnie przyzwoicie. Nie bito nas lub coś w tym rodzaju. Nie słyszałam też o żadnym gwałcie w obozie. Podczas pracy w kuchni sparzyłam się w nogę, rana oparzenia nie goiła się i zaczynała ropieć. Była ona coraz większa i głębsza. Następnie opatrzono mnie w lazarecie. Był tam, zdaje się, lekarz rosyjski i lekarka, którzy opatrzyli mi tę ranę maścią i prawie codziennie zmieniano opatrunek ${ }^{14}$.

10 W. Stankowski, Obozy i inne miejsca odosobnienia dla niemieckiej ludności cywilnej w Polsce w latach 1945-1950, Bydgoszcz 2002, s. 262.

11 Tamże, s. 263.

12 Tamże, s. 264.

13 Z. Woźniczka, Obóz NKWD w Toszku - 1945 r., „Rocznik Muzeum w Gliwicach” 2002, t. 17, s. 277-302.

${ }_{14}$ Przesłuchanie Ursuli Wilde, Krajowa Dyrekcja Policji Drezno, 13 maja 1993, odpis: OK. Ka/S 4/91 [w:] Z. Woźniczka, Obóz NKWD..., dz. cyt., s. 288. 
Jednym z najbardziej znanych na Górnym Śląsku był obóz w Świętochłowicach-Zgodzie. Więźniami „Zgody” były w zdecydowanej większości osoby po 40. roku życia. Dużą grupę, liczącą kilkuset więźniów, stanowiły osoby powyżej 60 . roku życia. W obozie przebywały również kobiety i dzieci. W czerwcu 1945 roku osadzono tam aż 716 kobiet (co stanowiło blisko $17 \%$ wszystkich pozbawionych wolności). W lipcu tego roku dużą grupę kobiet przetransportowano do Libiąża - filii Centralnego Okręgu Przemysłowego (COP) Jaworzno. Ostatecznie we wrześniu 1945 roku w obozie zostało ponad 300 kobiet. Wiele z nich zmarło w czasie epidemii tyfusu latem tego roku. Ludzie często byli doprowadzani do obozu bez żadnych dokumentów i przy spisywaniu ich personaliów opierano się na zeznaniach osób doprowadzających. Nie przedstawiano żadnych list ani nakazów aresztowania. Kiedy przyprowadzano więźniów w nocy, przetrzymywano ich na placu obozowym aż do rana. Musieli stać godzinami - często z podniesionymi rękoma, zanim zostali przydzieleni do poszczególnych baraków ${ }^{15}$. Dorota Boreczek tak wspomina pobyt $\mathrm{w}$ obozie:

Po kilku godzinach wolno nam było pójść do baraku. Zaprowadziła nas tam kapo. Nie posiadałyśmy przez cały czas pobytu żadnej łyżki czy miski. Jadłyśmy rękami z zardzewiałych puszek. Głód był tak okropny, że zbierałyśmy trawę i ją jadłyśmy. Przez cały czas nie widziałam mydła. Do mycia była tylko zimna woda. Obóz był przepełniony tak, że po pięć kobiet musiało dzielić ze sobą dwie prycze. Niektóre z nas siedziały całą noc na podłodze, z powodu braku miejsca na pryczy. Między poszczególnymi deskami było dużo wolnego miejsca, tak że więźniarki spadały na ziemię i na leżące tam kobiety i ranne. Niektóre pochodziły z bogatych domów, lub posiadały własne sklepy, jak np. p. Olga, którą zadenuncjowała sprzedawczyni, której powierzyła do ukrycia pewne kosztowności. Były tu różne kobiety od prostytutek do hrabiny. Część z nich zapewne zachowywała się niegodnie w czasie wojny. Rytm życia lagru wyznaczał rytuał apeli, mycia podłóg i jedzenia ${ }^{16}$.

W bloku kobiecym szefem (kapo) była kobieta, która często i brutalnie biła więźniarki. Agnieszka Cholewik przypomina sobie: „Staliśmy tam cały dzień, całą noc i cały następny dzień. Nie wolno nam było siedzieć. W baraku były trzypiętrowe prycze, spaliśmy na nich po trzy osoby, a także na podłodze. Kiedy chciałyśmy iść do latryny, to musiało się nas zebrać dziesięć osób” ${ }^{17}$. Więźniarka J.F. z Pszczyny wspomina:

Przybywszy do obozu Zgoda czekaliśmy godzinami na podwórku, czekając na przyjęcie. W dużym pokoju stały trzypiętrowe drewniane stelaże, na których można było

15 Z. Woźniczka, Represje na Górnym Śląsku..., dz. cyt., s. 266-270.

${ }_{16}$ M. Łuszczyna, Mata zbrodnia, polskie obozy koncentracyjne, Kraków 2017, s. 74-76.

17 Zeznania Agnieszki Cholewik, 30 czerwca 1993 [w:] Obóz Pracy w Świętochtowicach w 1945. Dokumenty, zeznania, relacje, listy, wybór, wstęp, oprac. A. Dziurok, Warszawa 2002, s. 126. 
przynajmniej się rozprostować po tym, jak w Bielsku tylko kucałyśmy na cementowej podłodze. Wyżywienie dostawaliśmy tylko raz dziennie: cienka zupa i mały kawałek chleba. To musiało wystarczyć do następnego dnia. Kobietom na rozkaz dowódcy obcięto całkowicie włosy. Młode dziewczyny, a pośród nich kilka wrażliwych artystek, odmawiały wykonania tego rozkazu i były zmuszane rewolwerem do oddania się owej procedurze. Bardzo szybko się rozchorowałam i nie mogłam pójść do pracy. Inne kobiety codziennie chodziły do Eintrachtshuette, gdzie przeładowywały żelazne pręty, płyty etc. ${ }^{18}$

Oprócz wyniszczającej pracy w kopalniach i bicia więźniów najbardziej dziesiątkowały choroby. Kiedy w środku lipca wybuchła epidemia tyfusu, sale wyglądały jak oddziały szpitalne:

Gdy w dzień przechodziło się przez baraki, nie widziało się już ani jednej pryczy bez leżącego tam chorego więźnia na tyfus. Na podłodze również leżeli wycieńczeni więźniowie. Ich jęki i skomlenia były nie do zniesienia, tak samo jak silny smród uryny i kału. Nikt już nie był w stanie uciec przed chmarami wszy ${ }^{19}$.

\section{Tak wspomina te czasy więźniarka J.F. z Pszczyny:}

Ja sama zachorowałam później również na tyfus. Leżeliśmy w barakach bez jakiejkolwiek pomocy i opieki lekarskiej. Wiele kobiet miało rozliczne rany, zapełnione na skutek panującego brudu rozlicznym robactwem. Leżałam przez kilka dni nieprzytomna na moim posłaniu i kiedy się obudziłam, w sali była już tylko jedna dziesiąta tych kobiet, które zachorowały razem ze mną. Rzeczy, których nie miałam bezpośrednio na ciele, zostały całkowicie skradzione. Kiedy byłam już w takim stanie, że samodzielnie mogłam utrzymać się na nogach, dostałam się do baraku dla uzdrowionych. Tam warunki były nieco lepsze. Była zupa ziemniaczana i kukurydziana ${ }^{20}$.

${ }_{18}$ Die Vertriebung der deutschen Bevölkerung aus den Gebieten östlich der Oder-Neisse, Munchen 1984, nr 215. Relacja pani J.F. z Pszczyny na Górnym Śląsku. Oryginał, 13 grudnia 1951 [tłum. Z.W.]. Pani J.F. dodaje, że „Codziennie przywożono nowych więźniów, których zwykle aresztowano w Gliwicach, gdzie kontrolowano wszystkich podróżujących. Po przesłuchaniu przywożono ich do naszego obozu. Mimo przepełnionych baraków, codziennie przybywały nowe transporty mężczyzn. Stali noce i dnie na podwórku, byli przesłuchiwani i bici, a potem odtransportowano ich do pracy w kopalniach. Stamtąd nikt już nie wracał. Pośród tych osób byli też mieszkańcy naszego miasta, z którymi jeszcze rozmawiałam, a o których do dziś nic już nie słyszałam”. Tamże.

${ }_{19}$ G. Gruschka, Zgoda - miejsce grozy. Obóz koncentracyjny w Świętochtowicach, tłum. M. Wolny, Gliwice 1998, s. 51.

${ }^{20}$ Die Vertriebung..., dz. cyt., nr 215. Relacja pani J.F. z Pszczyny na Górnym Śląsku. Oryginał, 13 grudnia 1951 [tłum. Z.W.]. 
Bicie, głód i pobyt w obozie czyniły spustoszenie w psychice więźniów, którzy byli coraz bardziej zobojętniali na śmierć innych. Cytowana już Dorota Boreczek, która jako 14-letnia dziewczyna została uwieziona w obozie razem z matką, opowiada jak bito w obozie młodą, 20-letnią dziewczynę z Bytomia lub Gliwic, konduktorkę tramwajową, którą aresztowano, gdyż nie umiała mówić po polsku. Gdy zachorowała, pobiła ją do nieprzytomności funkcyjna Piwko, Niemka z Gliwic, podobno członkini NSDAP. Wszyscy uznali, że dziewczyna nie żyje, leżała bowiem bezwładna na ziemi. Więźniarki rozebrały ją do naga i wyrzuciły jak sądziły, zwłoki przez okno. Stamtąd zabrali ją mężczyźni więźniowie, wywożący trupy z obozu. Jednak jej nie zdążyli wywieźć. „W nocy drzwi się otwarły, a ona weszła do baraku, naga. Wydostała się spod stosu trupów. To nie zrobiło na nas żadnego wrażenia. Było normalne"21.

Dorota Boreczek podaje też i taki przypadek: jedna z więźniarek zaprosiła ją zmarzniętą do pryczy pod koc, aby się ogrzała. Rano, gdy się obudziła, stwierdziła, że kobieta ta nie żyje. „Gdy to pojęłam, poczułam tylko szczęście. Miałam koc, byłam bogata!"22.

Podobnych zeznań było więcej. Kobiety mówiły też współwięźniarkom i współwięźniom, że były bite i gwałcone. Henryk Wowra zeznał 30 kwietnia 1998 roku: „Od dziewczyn słyszałem, że były gwałcone. Moim zdaniem były one traktowane nawet gorzej niż my"23. Agnieszka Cholewik wyznaje po latach: „Bito więźniarki w odosobnieniu z reguły w czasie nocy. Nie słyszałam o przypadkach zgwałceń" ${ }^{24}$.

Oprócz tych dramatycznych opisów były jednak i takie, w których autorki nie wspominały o biciu czy gwałtach popełnianych w obozie. Melania Uherek zeznała:

W baraku, w którym przebywałam, były same kobiety. Niektóre kobiety z mojej sali chodziły do pracy na kopalnie Polska i tam sprzątały. Ja też wołałabym chodzić do pracy, niż siedzieć i ciągle tylko wpatrywać się w okno, ale nigdy nie zostałam wyznaczona do pracy poza obozem. Każdy musiał utrzymywać porządek w swoim kącie, poza tym były wyznaczane tygodniowe dyżury i wtedy kolejno byłyśmy odpowiedzialne za sprzątanie i porządek całej sali. Nie mogłyśmy opuszczać sali i wychodzić na zewnątrz, tylko do ubikacji mogłyśmy wychodzić poza barak ${ }^{25}$.

Można stwierdzić, że ta kobieta miała szczęście.

${ }^{21}$ D. Boreczek, Stygmaty nienawiści, oprac. A. Kontek, „Dziennik Zachodni”, 14.12.2007, s. $16-17$.

${ }^{22}$ Tamże.

${ }^{23}$ Zeznanie Henryka Wowry z 30 kwietnia 1998 [w:] Obóz Pracy w Świętochtowicach..., dz. cyt., s. 150.

${ }_{24}$ Zeznanie Agnieszki Cholewik z 30 czerwca 1993 [w:] Obóz Pracy w Świętochtowicach..., dz. cyt., s. 126.

${ }^{25}$ Relacja Melanii Uherek z 6 sierpnia 2001 [w:] Obóz Pracy w Świętochtowicach..., dz. cyt., s. 176. 
Ciężki był los kobiet również w obozie pracy w Mysłowicach. Powstał on w czasie drugiej wojny światowej, kiedy było tutaj Polityczne Więzienie Zastępcze, nazywane „śląskim Pawiakiem”. Wieziono i mordowano w nim polskich patriotów od powstania obozu w lutym 1941 do jego likwidacji 26 stycznia 1945 roku. Od czasów wojny obóz nazywano „Rosengarten”, czyli Ogród Róż. Jedna z wersji mówi, że nazwa pochodzi od istniejącego tam przed wojną rozarium, z kolei druga - iż nazwa pochodzi od tak zwanego kołowrotu, czyli wału nabitego gwoździami, do którego przywiązywano więźniów ${ }^{26}$.

Od lutego 1945 roku komunistyczny aparat represji ponownie uruchomił obóz, zamykając tam ludzi należących w czasie drugiej wojny światowej do organizacji nazistowskich, żołnierzy Wehrmachtu, a także tych, którzy podpisali volkslistę, posiadali obywatelstwo niemieckie. 1 kwietnia 1945 trzymano już w nim 2933 mężczyzn i 556 kobiet, 1 lipca - 3419 mężczyzn i 851 kobiet, 1 sierpnia 4043 mężczyzn i 1014 kobiet, a 1 grudnia 3414 mężczyzn i 644 kobiety. W ostatnich tygodniach funkcjonowania obozu we wrześniu 1946 roku przebywało w nim 879 więźniów. W sumie, według obliczeń Wacława Dubiańskiego, w obozie w Mysłowicach przebywało 13868 osób. W wyniku ciężkich warunków bytowania, terroru oraz wyniszczającej pracy i wynikających z tego epidemii zmarło w obozie co najmniej 2281 więźniów ${ }^{27}$.

Podobnie jak w całym kraju do załogi obozu pracy w Mysłowicach należała straż obozowa z naczelnikiem na czele. Pierwszym z nich był Tadeusz Skowyra, który swój urząd piastował od lutego do grudnia 1945 roku. Drugim naczelnikiem był Konrad Brabański. Sprawował on swoją funkcję jedynie przez trzy miesiące, od grudnia 1945 do połowy marca 1946 roku, kiedy to zastąpił go trzeci i tym samym ostatni zarządca obozu, Eugeniusz Oczkowski. Swoją funkcję pełnił do zamknięcia obozu, to jest do 4 listopada 1946 roku. Na personel obozu składało się ponad 100 funkcjonariuszy więziennictwa. Wśród pracowników panowała niska dyscyplina bądź nie było jej wcale. Nad osadzonymi znęcali się nie tylko strażnicy, ale także pracujące tam strażniczki, stanowiące około $15 \%$ służby więziennej. Zachowanie konwojentów, którzy eskortowali więźniów do pracy, również było naganne. Zakazywali oni przechodniom oraz więźniom kontaktów. Znany jest przypadek, kiedy jedna $\mathrm{z}$ kobiet na ulicy próbowała porozmawiać $\mathrm{z}$ idącym $\mathrm{w}$ kolumnie więźniów ojcem, w wyniku czego zaczęto do niej strzelać, a ojca po powrocie do zakładu wychłostano. Rodziny osadzonych wspomagały swoich bliskich przez dostarczanie paczek z żywnością. Przekazywane były one przez strażników. Aby przesyłka dotarła, przekazujący starali się przekupywać funkcjonariuszy wódką. Do więźniów jednak trafiała jedynie część zawartości lub paczka nie docierała w ogóle. Ich grabież przez personel była powszechna. Nie należały

26 W. Dubiański, Obóz pracy w Mystowicach 1945-1946, Katowice 2004.

27 Tamże. 
do rzadkości sytuacje, kiedy strażnicy dla własnych korzyści odbierali paczki dla zmarłych więźniów, nie informując rodziny o śmierci ich bliskiego ${ }^{28}$.

Więźniowie byli bici i głodzeni w samym obozie, ale też w miejscu pracy, a więc w okolicznych kopalniach. Do lipca 1945 roku obóz w Mysłowicach dostarczył górnictwu 2250 przymusowych robotników. Pracowali oni w takich kopalniach, jak: Paryż, Niwka, Śląsk, Mysłowice, Klimontów oraz w innych zakładach Zagłębia Dąbrowskiego i Chrzanowskiego. Kobiety były bite w obozie, gwałcone, a także zmuszane do pracy na dole w kopalniach. Według świadectwa Krystyny Raiman, która przebywała w obozie na przełomie lutego i marca 1945 roku wraz z matką w dużej celi, w której umieszczono 250 kobiet, spano na trzypiętrowych pryczach. Początkowo nakrywano się jakimś szmatami, ale kiedy uległy one zawszeniu, zostały wyrzucone i odtąd więźniarki spały na gołych deskach bez pokrycia (cele nie były ogrzewane) ${ }^{29}$.

Należy wspomnieć, że w obozie w Mysłowicach znalazła się też Irmgarda Swinarska wraz z 16-letnim synem Konradem, który był później znanym reżyserem teatralnym, telewizyjnym inscenizatorem i scenografem. Pochodziła z mieszanej polsko-niemieckiej rodziny, jakich było wiele w tamtym czasie na Górnym Śląsku. Ojciec Irmgardy był powstańcem wielkopolskim, a matka Niemką, natomiast mąz - przedwojennym oficerem wojska polskiego. Ludzie ci w czasie wojny i po niej stawali przed trudnymi wyborami, czy opowiadać się za Niemcami, czy za Polską. Byli też często tragicznie doświadczani przez Niemców lub Polaków. Tak było i w rodzinie Swinarskich. W 1935 roku umarł Karol, mąż Swinarskiej, która została wdową wychowującą dwóch synów: Konrada i Henryka. Podpisywała się von Swinarska, była zamożna. Po 1939 roku - jak wielu - podpisała volkslistę i afiszowała się z niemieckimi oficerami. Jej synowie chodzili do niemieckiej szkoły i jeździli na wakacje do Rzeszy. Ale jednocześnie Irmgarda pomagała ukrywającym się Polakom, chroniła ich przed represjami. Pod koniec wojny 17-letni Henryk zaciągnął się do Waffen SS i zginął 8 marca 1945 roku. Po wojnie Swinarska z młodszym synem Konradem wróciła do Katowic. Tutaj zostali zadenuncjowani przez sąsiadów i zamknięci jako Niemcy w obozie w Mysłowicach. Konrada szybko zwolniono, zamieszkał sam w Katowicach. Opiekowała się nim dalsza rodzina ze strony ojca. Natomiast Swiniarska została w obozie i po kilku miesiącach umarła na tyfus. Konrad uczył się w LO im. A. Mickiewicza w Katowicach. Władze wytykały mu pochodzenie niemieckie, jednak udało mu się zdać maturę i skończyć studia ${ }^{30}$.

$\mathrm{Na}$ tle śląskich obozów pracy wyróżniały się Łambinowice. Obóz ten został zasiedlony przez ludność wiejską, którą spędzono do dawnego obozu

28 Tamże.

29 Tamże, s. 36.

${ }^{30}$ G. Kuźnik, W Katowicach zrozumiat, co to los, strach, mitość, „Dziennik Zachodni”, 30.03.2012, nr 76 . 
niemieckiego, robiąc w ten sposób miejsca dla czekających na gospodarstwa przesiedleńców ze Wschodu. Przetrzymywano tu mieszkańców z 30 okolicznych miejscowości z powiatów niemodlińskiego i nyskiego. Byli to zarówno mężczyźni, jak i kobiety oraz dzieci. Z powodu bardzo złych warunków higienicznych, głodu tortur i bicia zmarło około 1,5 tysiąca osób ${ }^{31}$. Obóz zlikwidowano w październiku 1946 roku.

Więźniowie obozu mieli być wywożeni w ramach wysiedlenia do Niemiec, ale wcześniej wykorzystywano ich jako tanią siłę roboczą do prac w polu, lasach i przemyśle. Dotyczyło to osób mówiących językiem niemieckim, choć zamykano również posługujących się mową śląską. Sołtys wsi Kuźnica Ligocka, pan Staisz, przypomina sobie te czasy:

Wojsko polskie i cywile w sposób brutalny wypędzali ludzi z mieszkań (...). Widziałem osobiście, że podczas akcji żołnierze i cywile bili miejscową ludność oraz rabowali ubrania, obrączki i inne wartościowe przedmioty (...), musieli pieszo przejść $12 \mathrm{~km}$ do Łambinowic. W czasie drogi żołnierze polscy i cywile bili tych ludzi, którzy nie mogli iść (...). Po przybyciu na teren obozu zostaliśmy dotkliwie pobici przez strażników ${ }^{32}$.

Ludzie ci byli wysiedlani ze wsi, a na ich miejsce czekali już przesiedleńcy ze Wschodu. W relacji Łucji Kurian czytamy:

28 września 1945 r. wieś Ligota Tułowicka została otoczona przez MO i UB. Rozkazano nam wszystkim zebrać się na pastwisku. Ponieważ nie byliśmy uprzedzeni o wysiedleniu, zdążyliśmy zabrać tylko odzież i trochę żywności. Nie wiedzieliśmy, co nas czeka, jednak wszyscy spodziewali się, że wywiozą nas z wioski. Osadnicy czekali już na gospodarstwa i mieszkania. Pytano się, kto jest Polakiem. Matka zgłosiła się, że potrafi mówić po polsku. Ponieważ reszta rodziny nie potrafiła, wszystkich nas zabrano do obozu. Mężczý́ni szli pieszo. Kobiety z dziećmi jechaty na samochodach ${ }^{33}$.

Po przybyciu do obozu więźniowie byli bici, a nawet zabijani przez strażników. Podobnie jak w innych obozach, byli nimi w przeważnie przypadkowi kryminaliści, którzy czuli się całkowicie bezkarni. Wzywali oni też do siebie kobiety, dziewczyny i gwałcili je na oczach innych. Gwałcenie kobiet przez strażników było powszechne, o czym świadczą liczne relacje ${ }^{34}$. Niezamężna Magda Walke

31 E. Nowak, Cień Eambinowic. Próba rekonstrukcji dziejów Obozu Pracy w Łambinowicach 1945-1946, Opole 1991; tenże, Obóz Pracy w Eambinowicach (1945-1946) [w:] Obozy $w$ LamsdorflEambinowicach (1870-1946), red. E. Nowak, Opole 2006.

32 J. Ruszewski, Ziemia tragiczna, „Tygodnik Powszechny” 1990, nr 19.

${ }^{3}$ E. Nowak, Cień Eambinowic..., dz. cyt., s. 81-82.

${ }^{34}$ Tamże. 
z Bielic (Bielitze) zapisała, że w czasie pobytu w obozie kobiety musiały ciężko pracować, między innymi na polach wokół obozu.

Zaprzęgnięto do ciężkiego gospodarczego wozu, który musieliśmy ciągnąc, jadąc do pobliskich wiosek po kartofle lub zajmować się sprawami gospodarczymi na polach. Ponieważ nie było zwierząt pociagowych, zaprzęgano nas, kobiety, do walcowania pól lub ciągnięcia bron. Nie mając żadnych narzędzi rolniczych do dyspozycji, musiałyśmy ziemniaki wykopywać gołymi rękami. Do 15 kilometrów od obozu były rozrzucone pola, z których ciągnęliśmy pełne wozy kartofli. Polscy milicjanci bili nas cały czas: przy pracy i ciągnięciu wozów. W obozie nie byłyśmy bezpieczne ani przez chwilę. Polacy strzelali dla rozrywki do niektórych kobiet. Panna Hedwig Apostel została ranna w twarz, a pani Marii Wanske strzelono dwukrotnie w brzuch, kiedy czekała przed latrynami na swoją kolejkę. Męczyła się jakiś czas, aż w końcu zmarła. Również w nocy nie mieliśmy spokoju. Do późnej jesieni, gdzie noce są już na Śląsku bardzo zimne, nasz barak nie posiadał szyb, mimo to musiałyśmy spać jedynie w koszulach. Prawie każdej nocy przychodzili wartownicy, zrywali z nas przykrycie, aby skontrolować czy śpimy w majtkach. Sporo kobiet i dziewcząt przy tej okazji zgwałcono. Te, które spały w majtkach lub miały inne rzeczy prócz koszuli na sobie, były bite knutem (bat używany do chłostania skazańców) po twarzy, wyganiane z łóżek i traktowane kopniakami w brzuch, gdyż uważano, że przygotowały się do ucieczki. Wypędzano je poza barak - w środku nocy - i nakazano jako karę ćwiczenia gimnastyczne ${ }^{35}$.

2 września 1945 z pracy w polu powróciło 100 kobiet, którym strażnicy kazali maszerować wzdłuż placu i każda z nich dostała 25 uderzeń kijami. U niektórych została przecięta skóra. Część zmarła w cierpieniach ${ }^{36}$. Najbardziej szykanowani byli nauczyciele, urzędnicy, kupcy i księża. Milicja często wbijała niektórym więźniom igły za paznokcie, kneblowano ich, polewano moczem i ekskrementami (na przykład Alois St. z Pruszkowa), kazano mężczyznom i kobietom rozbierać się i biciem zmuszano do różnych sadystycznych poczynań seksualnych czy do jedzenia ekskrementów (inż. Sch. z Berlina). Ponadto ciężko chore kobiety i 14-letnie dziewczyny były gwałcone ${ }^{37}$.

W obozie ofiarami śmierci padały całe rodziny. Zginęła między innymi rodzina gospodarza Artel. Ojcu Josefowi rozbito głowę szpadlem. Obozu nie przeżyły także jego żona Agnes, córka Therese i z najbliższej rodziny Hedwig z domu Micklitz; Gretel z domu Langfeld, mężatka i jej 3-letnia córka Helga; wdowa Maria; Helene z domu Simmchen i jej dziecko Mariechen. Anna została żywcem pogrzebana ${ }^{38}$.

Sadyzm strażników nie miał granic. Kobiety musiały patrzeć na zakopywanie zwłok swoich zmarłych, gdy po pogrzebaniu kilka z nich zebrało

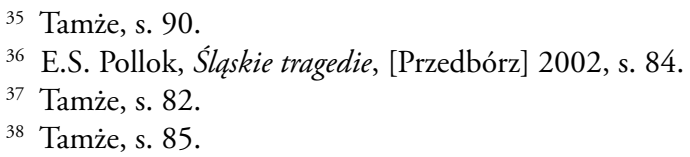


kwiatki polne i wetknęło je do ziemi, gdzie leżały bliskie im sercu osoby (dzieci, mężowie, bracia, siostry), strażnicy zakatowali je za to na śmierć39.

Największym obozem, gdzie przetrzymywano Górnoślązaków, był Centralny Obóz Pracy w Jaworznie. Powstał on już w lutym 1945 roku, kiedy to na terenie dawnego niemieckiego podobozu KL Auschwitz władze komunistyczne zaczęły zamykać pierwszych więźniów ${ }^{40}$. Komendantami obozu byli kolejno: Włodzimierz Staniszewski, Stanisław Kwiatkowski, Teofil Hazelmajer i Salomon Morel. W skład obozu wchodziły podobozy, w których wieziono Polaków, internowanych Górnoślązaków wpisanych na niemiecką listę narodowościową (volkslistę) oraz jeńców wojennych, w tym pochodzących z formacji Waffen SS. W latach 1947-1949 w obozie umieszczano ponadto obywateli polskich narodowości ukraińskiej, wysiedlanych z terenów wschodniej i południowej Polski w ramach akcji „Wisła”. Podejrzewano ich o współudział w działalności nacjonalistycznych organizacji ukraińskich: UPA (Ukraińska Powstańcza Armia) i OUN (Organizacja Ukraińskich Nacjonalistów) ${ }^{41}$. Baraki obozu mogły pomieścić od 3500 do 4500 osób. W rzeczywistości obóz był przepełniony, gdyż w latach 1946-1948 więziono tam od 3250 do 7150 osób.

Według pierwszego zachowanego raportu z 22 marca 1945 roku w Jaworznie przebywało 1911 więźniów (945 mężczyzn i 935 kobiet), a 357 więźniów pracowało poza obozem ${ }^{42} .1$ stycznia 1946 roku w Centralnym Obozie Pracy w Jaworznie więziono 5327 mężczyzn (w tym 381 jeńców wojennych). $\mathrm{Z}$ tej liczby w samym Jaworznie było 1871, a reszta w podległych podobozach. Kobiet było 2622, z tego w Jaworznie 1634, a reszta w podległych podobozach. Do tej liczby więźniów należy dodać 38 dzieci. Razem stanowiło

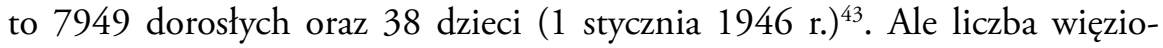
nych ciągle rosła i przykładowo 1 maja 1947 w obozie przebywało „zbrodniarzy faszystowskich i współpracujących z okupantem" - 63 mężczyzn i 13 kobiet, volksdeutschów: 1872 mężczyzn i 1783 kobiety. W czerwcu 1947 roku w obozie znajdowało się 942 Ukraińców, określanych jako przestępcy antypaństwowi i więźniowie śledczy. Były wśród nich kobiety ${ }^{44}$. Miesiąc później liczba osadzonych w obozie Ukraińców wzrosła do 2300, a we wrześniu tegoż

39 Tamże, s. 87-88, 90.

40 Szerzej pisze o tym K. Miroszewski, zob. tenże, Powstanie i funkcjonowanie Centralnego Obozu Pracy w Jaworznie (1945-1949), „Dzieje Najnowsze” 2002, nr 2; Historia martyrologii więźniów obozów odosobnienia w Jaworznie 1939-1956, red. K. Miroszewski, Z. Woźniczka, Jaworzno 2002; Obóz dwóch totalitaryzmów. Jaworzno 1943-1956, t. 1, red. K. Miroszewski, Z. Woźniczka, t. 2, red. R. Terlecki, Jaworzno 2007.

41 K. Miroszewski, Centralny Obóz Pracy Jaworzno. Podobóz ukraiński (1947-1949), Katowice 2001.

42 Archiwum Państwowe w Krakowie (dalej: AP Kraków) WOBP, sygn. UBKr 27.

43 AAN Warszawa MBP, Dep. Więziennictwa, sygn. 7/13, Wykaz ilościowy ludzi w Centralnym Obozie Pracy w Jaworznie ustalony w dniu inwentaryzacji, 1 stycznia 1946.

${ }_{44}$ AP Kraków, sygn. UBKr 27, Raport statystyczny o stanie zaludnienia COP w czerwcu 1947. 
roku osiągnięto stan najwyższy -3100 . $Z$ tego zginęło około $160^{45}$. 7 sierpnia 1947 roku zaludnienie COP w Jaworznie wynosiło 5430 osób, a stale przebywało w pracy poza obozem 8519 osób $^{46}$. Na początku grudnia 1947 roku w COP Jaworzno pozostawało 6227 osób, a poza obozem 6790 osób ${ }^{47}$. Potem liczba więźniów malała. W listopadzie 1948 przebywało stale w obozie 2628 osób (w tym 10 dzieci), a zatrudnionych poza obozem było $4309^{48}$. W lutym 1949 roku więziono 2522 osoby, poza obozem pracowało $3813^{49}$.

Według obliczeń Kazimierza Miroszewskiego do grudnia 1950 roku przez COP Jaworzno przeszło 23669 więźniów, a z tej liczby zmarło $6987^{50}$. Dawało to, jak się wydaje, niechlubne pierwsze miejsce wśród najgorszych obozów pracy w Polsce.

\section{Praca niewolnicza}

W tym wielkim obozie bito, torturowano i gwałcono więźniarki, ale z biegiem czasu skala tych patologii malała. Dlaczego? Władzę wprowadzały dyscyplinę i „dbały o więźniów”, którzy byli przecież cenną siłą roboczą. Najbardziej wyniszczającą represją była więc ciężka, niemal niewolnicza praca więźniów i więźniarek. Kobiety pracowały w obozach w znajdujących się tam warsztatach oraz w zakładach przemysłowych i w kopalniach; na przykład w COP w Jaworznie w 1947 i na początku 1948 roku w obozowych warsztatach pracowało dzień i noc 3000 więźniów. W warsztatach krawieckich znajdowało się 400 maszyn do szycia. Kobiety i mężczyźni pracowali tam po 10 godzin, od godziny 4.00 do 12.00 oraz od 12.00 do 22.00. Warsztat krawiecki mógł wyprodukować dziennie 4000 mundurów. Więźniowie otrzymywali premie $\mathrm{w}$ formie dodatkowego jedzenia. Większość tych kobiet nigdy wcześniej nie zajmowała się krawiectwem. Przodowniczki pracy otrzymywały specjalne chorąiewki. Więźniarki nie były bite, dbano o dyscyplinę pracy. Na 400 kobiet była tylko jedna strażniczka ${ }^{51}$.

Powszechną formę represji wobec kobiet stanowiło zmuszanie ich do ciężkiej pracy pod ziemią w kopalniach. Nastręczało to polskim Zjednoczeniom Przemysłu Węglowego i kierownictwu Centralnego Zarządu Przemysłu Węglowego (CZPW) problemów prawnych. Nadal bowiem obowiązywały przedwojenne przepisy, na mocy których zabraniano zatrudniać pod ziemią kobiety

${ }^{45}$ AP Kraków, sygn. UBKr 27, Raporty statystyczne.

${ }^{46}$ AP Kraków, sygn. UBKr 25, Pismo Naczelnika Wydziału Więziennictwa WUBP w Krakowie do Naczelnika Wydziału Finansowego tegoż Urzędu z 7 sierpnia 1947.

${ }^{47}$ AP Kraków, sygn. UBKr 25, Pismo Naczelnika Wydziału Więziennictwa WUBP w Krakowie do Naczelnika Wydziału Finansowego tegoż Urzędu z 3 grudnia 1947.

${ }^{48}$ AP Kraków, sygn. UBKr 25.

49 Tamże.

50 K. Miroszewski, Centralny Obóz Pracy Jaworzno..., dz. cyt., s. 15.

${ }^{51}$ B. Kopka, Obozy pracy w Polsce 1944-1950. Przewodnik encyklopedyczny, Warszawa 2002, s. 196-197. 
i młodocianych. Jednak ze względu na brak rąk do pracy zdecydowano się łamać prawo i zatrudniać kobiety. Nie miano natomiast żadnych skrupułów, zatrudniając więźniarki znajdujące się w obozach CZPW. Uznano je za Niemki, a tym samym odmawiano im praw należnych obywatelom Rzeczypospolitej Polskiej. Przedwojenne ustawodawstwo niemieckie zezwalało na pracę kobiet pod ziemią w kopalniach (podobnie było w ZSRR) ${ }^{52}$. W pismach zarządów zjednoczeń węglowych pisano wówczas: „sądzimy, że nie mamy w tej chwili potrzeby zabiegać o to, aby zmianie uległo niemieckie prawo, zezwalające na pracę kobiet pod ziemią. Niech to niemieckie prawo znajdzie zastosowanie do niemieckich kobiet tak długo - jak to nieodzownie i koniecznie będzie potrzebne" ${ }^{53}$.

\section{Represje po obozie}

Kobietom nie wolno było mówić o tym, co ich spotkało w obozie. Dorota Boreczek wspomina to następująco: „Kazali nam przysiąc, że do końca życia nie powiemy o tym, co przeżyłyśmy i widziałyśmy. Mama nawet umierając, mówiła: "Wiesz, ja też byłam w więzieniu, ale tam było nadzwyczaj dobrze. Nikt nam nie zrobił nic złego «" 54 . Oprócz traumy byli więźniowie mieli też problemy z codzienną egzystencją, gdyż skonfiskowano im mieszkania. Uwolnieni nie tylko nie mieli dachu nad głową, ale także nie mogli znaleźć pracy, a ich dzieci zamiast chodzić do szkół musiały pracować lub żebrać. Taki los spotkał na przykład rodzinę 8-letniego wówczas Joachima Nowaka, więźnia obozu w Świętochłowicach-Zgodzie (od lutego do października 1945 roku):

Represje wobec mojej rodziny trwały nadal. Ojciec musiał dwa razy na dzień meldować się na posterunku milicyjnym, cały rok musiał pracować za darmo, bez zapłaty, matka pracowała przy budowie torów kolejowych w Wełnowcu za garnuszek zupy i jedną kromkę chleba. Pamiętam, że przyniosła to do domu, to było jej całe wynagrodzenie ${ }^{55}$.

Wspomniana już małoletnia Dorota Boreczek z Katowic po wyjściu z obozu w Świętochłowicach-Zgodzie zamieszkała z chorą matką z piwnicy swojej kamienicy, którą im skonfiskowano, podobnie jak całe ruchome mienie rodziny oszacowane na ówczesnych 7,5 miliona złotych (zarobki miesięczne średnio wynosity w tym czasie 750 złotych). Niekiedy pomagali jej ludzie, którzy kiedyś u nich pracowali. Pobyt w obozie i dokuczliwe szykany wycisnęly piętno na jej psychice ${ }^{56}$.

\footnotetext{
52 Tamże, s. 66.

3 Cyt. za: tamże.

D. Boreczek, dz. cyt., s. 17.

Cyt. za: Z. Woźniczka, Represje na Górnym Ślasku..., dz. cyt., s. 373.

${ }^{6}$ Relacja Doroty Boreczek w posiadaniu autora.
} 


\section{Zakończenie}

Los kobiet w obozach na Górnym Śląsku po zakończeniu wojny był konsekwencją tragicznej sytuacji, w jakiej znalazły się narody Europy tuż po wojnie. Radości wyzwolenia towarzyszyło szukanie winnych, a także represje i gwałty. Kobiety stały się w pierwszej kolejności ofiarami zemsty ze strony mężczyzn, za ich prawdziwą lub wyimaginowaną współpracę z okupantem. Ponadto armie zwycięzców, zarówno na Wschodzie, jak i na Zachodzie, traktowały kobiety na zajętych terenach jako „zdobycz”, a gwałcono nie tylko Niemki. Szczególnie liczne i krwawe były represje w Europie Środkowo-Wschodniej ze strony żołnierzy Armii Czerwonej.

Represje w obozach stanowiły swoistą „kontynuację” tych, jakich często doznawały już wcześniej. Kobiety w czasie wojny zamykano w rozmaitych obozach. $\mathrm{Na}$ Górnym Śląsku były to najpierw tak zwane obozy dzikie, a potem różnego rodzaju obozy pracy. W odróżnieniu od okresu wojny nie chodziło o ich masową eksterminację, ale o izolację tak zwanych Niemców, a następnie poddanie ich weryfikacji narodowościowej. Ci, których uznano za Niemców, mieli zostać wysiedleni do Niemiec, a uznani za Polaków - wrócić do swoich domów i uzyskać prawa obywatelskie. W rzeczywistości wszystkich obrabowano, zamknięto w obozach, bito i wykorzystywano jako niewolniczą siłę roboczą. Gwałty, terror i morderstwa to działania zdegenerowanych strażników, często sadystów, którzy czuli się bezkarni. Należy pamiętać, że był to rezultat chaosu tuż po wojnie, inercji władz obozowych i osób zarządzających na szczeblu wojewódzkim oraz centralnym. Władze nie nakazywały mordowania, gwałcenia osadzonych, ale przeciwnie - wzywały do wprowadzenia porządku i dyscypliny. Ludzi tych nie miano mordować, ale wykorzystywać do pracy, reedukować, wysiedlać etc. Dała jednak o sobie znać demoralizacja społeczeństwa, które mściło się na „Niemcach” za doznane czy wyimaginowane krzywdy.

W obozach skala represji była największa w 1945 roku, potem słabła, a bicie zastąpiła wyniszczająca praca w zakładach przyobozowych, w śląkich zakładach pracy, w tym w kopalniach. Wiele kobiet pracowało ciężko na dole przy wydobyciu węgla.

Po wyjściu w obozów kobiety miały duże trudności z adaptacją do nowych warunków życia. Często utrudniało to lub wręcz uniemożliwiało założenie rodziny, wychowywanie dzieci. Pozostała silna trauma obozowa, która prześladowała je do końca życia.

\section{Bibliografia}

\section{Archiwa}

Archiwum Akt Nowych Warszawa.

Zespół MBP 1944-1946, Departament Więziennictwa i Obozów.

Archiwum Państwowe w Katowicach.

Zespół: Centralny Zarząd Przemysłu Węglowego. 
Archiwum Państwowe w Krakowie.

Zespół Wojewódzkiego Urzędu Bezpieczeństwa Publicznego i Wydziału Więziennictwa i Obozów w Krakowie.

\section{Dokumenty publikowane}

Die Vertriebung der deutschen Bevölkerung aus den Gebieten östlich der Oder-Neisse, Munchen 1984, nr 215.

Obóz Pracy w Świętochtowicach w 1945. Dokumenty, zeznania, relacje, listy, wybór, wstęp, oprac. A. Dziurok, Warszawa 2002.

\section{Pamiętniki}

Gruschka G., Zgoda - miejsce grozy. Obóz koncentracyjny w Świętochtowicach, tłum. M. Wolny, Gliwice 1998.

\section{Wywiady}

Boreczek D., Stygmaty nienawiści, oprac. A. Kontek, „Dziennik Zachodni”, 14.12.2007.

\section{Literatura przedmiotu}

Borodziej W., Wstęp [w:] Niemcy w Polsce 1945-1950. Wybór dokumentów, t. 1, red. W. Borodziej, H. Lemberg, tłum. M. Cegielska, Warszawa 2000.

Dominiczak H., Organy bezpieczeństwa PRL 1944-1990. Rozwój i dziatalność w świetle dokumentów MSW, Warszawa 1997.

Dubiański W., Obóz pracy w Mystowicach 1945-1946, Katowice 2004.

Historia martyrologii więźniów obozów odosobnienia w Jaworznie 1939-1956, red. K. Miroszewski, Z. Woźniczka, Jaworzno 2002.

Irving D., Wojna Hitlera, tłum. B. Zborski, Warszawa 1996.

Kopka B., Obozy pracy w Polsce 1944-1950. Przewodnik encyklopedyczny, Warszawa 2002.

Kuźnik G., W Katowicach zrozumiat, co to los, strach, mitość, „Dziennik Zachodni”, 30.03.2012, nr 76 .

Łuszczyna M., Mała zbrodnia, polskie obozy koncentracyjne, Kraków 2017.

Miroszewski K., Centralny Obóz Pracy Jaworzno. Podobóz ukraiński (1947-1949), Katowice 2001.

Miroszewski K., Powstanie i funkcjonowanie Centralnego Obozu Pracy w Jaworznie (1945-1949), „Dzieje Najnowsze” 2002, nr 2.

Nowak E., Cień Eambinowic. Próba rekonstrukcji dziejów Obozu Pracy w Łambinowicach 1945-1946, Opole 1991. 
Nowak E., Obóz Pracy $w$ Eambinowicach (1945-1946) [w:] Obozy w Lamsdorfl Eambinowicach (1870-1946), red. E. Nowak, Opole 2006.

Obóz dwóch totalitaryzmów. Jaworzno 1943-1956, t. 1, red. K. Miroszewski, Z. Woźniczka, t. 2, red. R. Terlecki, Jaworzno 2007.

Pollok E.S., Śląskie tragedie, [Przedbórz] 2002.

Ruszewski J., Ziemia tragiczna, „Tygodnik Powszechny” 1990, nr 19.

Stankowski W., Obozy i inne miejsca odosobnienia dla niemieckiej ludności cywilnej $w$ Polsce $w$ latach 1945-1950, Bydgoszcz 2002.

Woźniczka Z., Obóz NKWD w Toszku - 1945 r., „Rocznik Muzeum w Gliwicach” 2002, t. 17.

Woźniczka Z., Represje na Górnym Śląsku po 1945 roku, Katowice 2013.

Wywózka. Deportacja mieszkańców Górnego Ślaska do obozów pracy przymusowej w Zwiazku Sowieckim w 1945 roku. Faktografia, konteksty, pamięć, red. S. Rosenbaum, D. Węgrzyn, Katowice 2014. 